\title{
Anti-inflammatory Effects of the Stem Barks from Albizia Ferruginea (Mimosaceae) on Chronic Inflammation Induced in Rats
}

\author{
Marc Germain Minoué Kuum ${ }^{1}$, Roméo Joël Temdie Guemmogne ${ }^{2}$, Martin Thierry Bella Ndzana ${ }^{* 1}$, \\ Jules Colince Tchadji ${ }^{1,3}$, Abel Lissom ${ }^{1,3}$, Théophile Dimo ${ }^{1}$ \\ ${ }^{1}$ Department of Animal Biology and Physiology, Faculty of Sciences, P.O Box 812, University of Yaounde I, Cameroon \\ ${ }^{2}$ Department of Biological Sciences, Faculty of Sciences, P.O Box 454, University of Ngaoundere, Cameroon \\ ${ }^{3}$ Laboratory of Microbiology and Immunology, Chantal BIYA International Reference Center for research on the \\ prevention and management of HIV/AIDS, P.O Box, 3077 Yaoundé-Messa, Cameroon
}

\section{*Correspondence for Author -}

Martin Thierry Bella Ndzana

Department of Animal Biology and Physiology, Faculty of Science, University of Yaounde I, P.0 Box 812, Cameroon, Email thierrybel2001@yahoo.fr

\begin{abstract}
Albizia ferruginea is used in popular medicine for the treatment of inflammatory illnesses. The chronic anti-inflammatory effects of aqueous extract of A. ferruginea was assessed on the cotton pellet-induced granuloma, formalin and complete Freund's adjuvant-induced inflammation. The aqueous extract of $A$. ferruginea was administered orally at the doses of 100 and $200 \mathrm{mg} / \mathrm{kg}$. It's showed that $A$. ferruginea extract (100 or $200 \mathrm{mg} / \mathrm{kg}$ ) significantly $(p<0.001)$ inhibited the granuloma formation induced by cotton pellets by $41.70 \%$ and $46.10 \%$, respectively. A. ferruginea extract, at the dose of $200 \mathrm{mg} / \mathrm{kg}$ inhibited $(p<0.01)$ the paw œdema induced by formalin $(25.79 \%)$ and Complete Freund's adjuvant (CFA) in rats(47.40\%).A. ferruginea extract(100 or $200 \mathrm{mg} / \mathrm{kg}$ ) normalized the level of white blood cells, red blood cells, hemoglobin, and platelets of rats treated with CFA. Glutathione and superoxide dismutase levels were significantly increase (92.59\% and $60.51 \%$, respectively), catalase activity was significantly increased (42.03\%) in the tissue of CFA rats treated with A. ferruginea (200 mg/kg). Malondialdehyde level was reduced by $72.88 \%(\mathrm{p}<0.01)$ in spleen of rats treated with $A$. ferruginea aqueous extract. The nitrite level was significantly decreased by $50.51 \%$ in liver of CFA rats treated with A. ferruginea $(200 \mathrm{mg} / \mathrm{kg})$. These results show that aqueous extract of A. ferruginea may possess antiinflammatory effects on chronic inflammation, which could be partially attributed to its antioxidant properties.
\end{abstract}

Keywords: Albizia ferruginea, Anti-inflammatory, Cotton pellet, Complete Freund's adjuvant, Formalin.

\section{Introduction}

Inflammation is the defensive reaction of the living organisms as response to noxious stimulation. The Chronic inflammation is a response to prolonged stimulation in the tissue ${ }^{[1]}$ The chronic inflammation is characterized by infiltration of leukocytes into the site of inflammation. This situation eventually leads to tissue deterioration, fibrosis and granuloma formation. The chronic inflammatory responses influences pathological evolution or increase of chronic illnesses. It is depicted or characterized by infiltration of these inflammatory cells, excessive production of cytokines, dysregulation of cellular signaling and loss of barrier function. ${ }^{[2]}$ The mechanism of chronic inflammation is attributed, in partly to release of reactive oxygen species from activated neutrophils and macrophages. This overproduction causes lipid peroxidation of membranes, which leads to tissue injury through damaging of macromolecules. ${ }^{[3]}$ In addition, ROS cause or extends inflammation by stimulating the release of cytokines such as interleukin-1, tumor necrosis factor $\alpha$ and interferon $\alpha$, which stimulates recruitment of additional neutrophils and macrophages. ${ }^{[4]}$ Thus, free radicals are important mediators that provoke and sustain inflammatory processes and consequently, their neutralization by antioxidants and radical scavengers can reduce inflammation. ${ }^{[5]}$ Among chronic illnesses, rheumatoid arthritis which is a greatly cause of disability, and is also considered the most common inflammatory disease. ${ }^{[6]}$ Attenuation of the chronic inflammatory response is a best strategy to fight against several human diseases. Although steroidal and nonsteroidal anti-inflammatory drugs are currently used to treat chronic inflammation disorders, due to the fact that they cause serious side effects. ${ }^{[7]}$ Most of pharmaceutical drugs originate from plants and the contribution of plants in drug discovery process is remarkable. Therefore, there is an urgent need to find safer antiinflammatory compounds in these plants. Traditional doctors uses many natural plant and unnatural as treatment options for a wide variety, including chronic inflammation. ${ }^{[8]}$ Natural products are 


\section{International Journal of Innovative Research in Medical Science (IJIRMS) Volume 03 Issue 09 Sept. 2018, ISSN: 2455-8737, Imp. Factor - 4.102 \\ Available online at $-\underline{w w w . i j i r m s . i n}$}

believed to be an important source of new chemical substance with potential therapeutic applicability. ${ }^{[9]}$ Cameroon is a rich source of medicinal plants and a number of these natural resources are used against diseases in the traditional medicine. A. ferruginea is a medicinal plants widely distributed in Cameroon and in other African countries. ${ }^{[10]}$

Albizia ferruginea stem barks are used in Cameroon folk medicine to treat chronic inflammation without evidence of their antiinflammatory effects. Traditionally, in Center region, Littoral and South regions of Cameroon, the stem barks of A. ferruginea are used to treat diarrhoea, rheumatism, abdominal and tooth pain, headache, bronchitis, dysentery and treat haemorrhoids and to draw out inflammation pain cause by fever. ${ }^{[11]}$ In Central Africa, a juice made from the leaves of $A$. ferruginea is used as emollient to soothe rashes, swellings, boils and carbuncles, the leaves are used to treat malaria. ${ }^{[12]}$ Leaves decoction is used as lotion or steam inhalation against fever, headaches and toothache. ${ }^{[13]}$

Phytochemical work show on that plant the presence of flavonoids, tannins, anthraquinones, cardiac glycosides, saponins, triterpens and carbohydrates and this molecules have most effects known anti-inflammatory effects. Flavonoids and flavonols exhibit inhibition of arachidonic acid peroxidation, which chemical mediators are implicated in chronic inflammation. ${ }^{[14]}$ But no systematic research have been done on the search of antiinflammatory effects. Therefore, the present study was designed to evaluate the anti-inflammatory effect of A. ferruginea on cotton pellet, formalin and Complete Freund's Adjuvant (CFA)-induced chronic inflammation in rats.

\section{Materials and Methods}

\section{Plant material}

The stem barks of A. ferruginea were harvested from Angallé village in the South Region of Cameroon, in March 2012. The plant materials were identified by Dr Barthélémy TCHIENGUE of the National Herbarium of Cameroon, where a voucher specimen of the plant was deposited under the number 49871 .

\section{Preparation of plant extract}

Fresh stem barks were air-dried and reduced to a fine powder. The powder $(500 \mathrm{~g})$ was macerated with $2.5 \mathrm{~L}$ of distilled water for 24 hours. The mixture was filtered with Whatman $\mathrm{N}^{\circ} 3$ filter paper, concentrated under reduced pressure and lyophilized at $50^{\circ} \mathrm{C}$ for 48 hours. A dark brown solid $(84 \mathrm{~g})$ representing the stem barks aqueous extract of A. ferruginea was obtained (yield of 16.8\%).

\section{Qualitative and quantitative phytochemical analysis}

The qualitative phytochemical investigations of the stem bark aqueous extract of Albizia ferruginea were performed for alkaloids, flavonoids, saponins, phenols, steroids, glycosides and tannins using standard methods previously described. ${ }^{[15,16]}$ The quantity of flavonols, total phenols, total flavonoids and total alkaloids content of the stem barks of A. ferruginea was determined by the standard methods. ${ }^{[17,18,19]}$ Quantification of the ascorbic acid of the extract of A. ferruginea was made using protocol described by Ghate et al. ${ }^{[20]}$ Briefly, $1 \mathrm{mg}$ of the extract of A. ferruginea was dissolved in $1 \mathrm{~mL}$ of distilled water. Then $1 \mathrm{~mL}$ of 2.4-Dinitro-Phenylhydrazin reagent was added in the mixture. After $15 \mathrm{~min}$ of incubation at $95^{\circ} \mathrm{C}, 5 \mathrm{~mL}$ of sulfuric acid $(85 \%)$ were dripped to the mixture submerged in a cold water $\left(5^{\circ} \mathrm{C}\right)$. After 30 minutes, the absorbance was read at $520 \mathrm{~nm}$ with a spectrometer (URIT-810, London). The different tubes have been triplicated. The ascorbic acid content is estimated in $\mathrm{mg}$ of vitamin $\mathrm{C} / \mathrm{g}$ of dry extract by using of vitamin $\mathrm{C}$ as standard.

\section{Animals}

Wistar albino rats (200-250 g) and Swiss albino mice (25-30 g) of both sex were obtained from the animal house unit of the Faculty of Science of the University of Yaounde I, Cameroon. They were maintained under standard environmental conditions with dark and light circle 12/12h. They were fed with standard commercial diet and water was provided ad libitum. The experimental protocol was in conformity with guidelines of the Cameroon National Ethical Committee on the use of laboratory animals for scientific research (CEEC Council 86/609).

\section{Pharmacological tests}

\section{Cotton pellet-induced granuloma in rat}

Cotton pellets-induced granuloma in rats was done according to the method of Sapna and Manish. ${ }^{[21]}$ Adult Wistar rats weighting 200$250 \mathrm{~g}$ were randomly divided into four groups of five in each. Rats were anaesthetized by valium $(0.5 \mathrm{~mL})$ and ketamine $(0.25 \mathrm{~mL})$, two sterilized cotton pellets weighing $10 \pm 1 \mathrm{mg}$ were implanted subcutaneously and bilaterally in axillary region of each rat under sterile conditions. The A. ferruginea extract (100 or $200 \mathrm{mg} / \mathrm{kg}$ ), diclofenac $(3.85 \mathrm{mg} / \mathrm{kg})$ was used as reference drug or distilled water $(10 \mathrm{~mL} / \mathrm{kg})$ were administered orally $30 \mathrm{~min}$ before implantation of the cotton pellet and once daily for seven consecutive days. At the end of administration, animals were sacrificed under anesthesia $(0.5 \mathrm{~mL}$ of valium and $0.25 \mathrm{~mL}$ ketamine). Group 1 received distilled water at the dose of 10 $\mathrm{mL} / \mathrm{kg}$ (Control), group 2 and 3 received aqueous extract at the doses of 100 and $200 \mathrm{mg} / \mathrm{kg}$ respectively. Group 4 received diclofenac at the dose of $3.85 \mathrm{mg} / \mathrm{kg}$ (reference). All treatments were given by gastric gavage for seven consecutive days from the day of cotton implantation. On the eighth day, rats were anesthetized and the cotton pellets surrounded with the granuloma tissue were carefully removed surgically and made free from connective tissues (humid weight). The wet cotton pellets surrounded with the granuloma tissue were weighted and then dried in an oven at $40 \pm 0.5^{\circ} \mathrm{C}$ for $24 \mathrm{~h}$, after that the dried weigh were measured (dry weight). The anti-proliferative effects of aqueous extract of $A$. ferruginea were determined by comparison to the control group. Percentage inhibition was calculated as follows:

\section{$\operatorname{Pi}(\%)=((1-G t) /(G c)) \times 100$}

$\mathrm{Pi}=$ Percentage inhibition; $\mathrm{GC}=$ Average weight of pellets in control group and $\mathrm{Gt}=$ Average eight of pellets in treated group.

\section{Formalin-induced paw oedema}

This experiment was undertaken using the methodology previously described by Ighodaro et al. ${ }^{[22]}$ Inflammation was induced by subcutaneous injection of $0.1 \mathrm{~mL}$ of formalin $(2 \%$ in $0.9 \% \mathrm{NaCl})$ in the right hind paw of the rats on the first and on the third day of the experiment. Adult Wistar rats weighting $200-250 \mathrm{mg} / \mathrm{kg}$ were used. Animals were then divided into four groups of five in each. A. ferruginea aqueous extract (100 or $200 \mathrm{mg} / \mathrm{kg}$ ), diclofenac $(3.85$ $\mathrm{mg} / \mathrm{kg})$ or distilled water $(10 \mathrm{~mL} / \mathrm{kg})$ were administered to rats 30 min before injection of formalin. The animals were treated once daily with the corresponding substances for 10 days. Group 1 (Control) received distilled water at $10 \mathrm{~mL} / \mathrm{kg}$. Group 2 and 3 


\section{International Journal of Innovative Research in Medical Science (IJIRMS) Volume 03 Issue 09 Sept. 2018, ISSN: 2455-8737, Imp. Factor - 4.102 \\ Available online at - $\underline{w w w . i j i r m s . i n}$}

received aqueous extract at the doses of 100 and $200 \mathrm{mg} / \mathrm{kg}$, respectively. Group 4 received diclofenac at the dose of 3.85 $\mathrm{mg} / \mathrm{kg}$ (reference). Inflammation was induced by injecting formalin $(2 \%, 0.1 \mathrm{~mL})$ into right hind limb of each rat under the subplantar aponeuvrosis on day zero and third day to induce progressive swelling of paw. The paw volume was determined with the plethysmeter (model 37140 UgoBasile, Italy) before and once daily for ten consecutive days after formalin injection. The ability of the drugs to reduce paw inflammation was expressed as a percentage of inhibition of paw œdema, calculated as follow:

$$
\operatorname{Pi}(\%)=\frac{(\mathrm{Vt}-\mathrm{Vo}) \text { control-(Vt-Vo)treated }}{(\text { Vt-Vo) } \text { control }} \times 100
$$

Where $\mathrm{Vt}=$ Average volume $(\mathrm{mL})$ for each group after treatment; Vo = Average volume $(\mathrm{mL})$ obtained for each group before treatment.

\section{Complete Freund's adjuvant (CFA)-induced arthritis}

Adjuvant-induced arthritis was done following the protocol described by Fotio et al., ${ }^{[23]}$ with some modifications. Adult Wistar rats weighting $200-250 \mathrm{mg} / \mathrm{kg}$ were used. Animals were then divided into five groups of five in each. Animals of group 1(normal control) were free of complete Freund's adjuvant, and were injected with $0.1 \mathrm{~mL}$ of $0.9 \% \mathrm{NaCl}$ in the left hind paw. Group 2 (control) received distilled water $(10 \mathrm{~mL} / \mathrm{kg})$. Group 3 and 4 received aqueous extract at the doses of 100 and $200 \mathrm{mg} / \mathrm{kg}$, respectively. Group 4 received diclofénac $(3.85 \mathrm{mg} / \mathrm{kg}$, reference drug). The animal of other groups received complete Freund's adjuvant $(0.1$ $\mathrm{mL} / \mathrm{rat}$ ), injected in their left hind paw. Injection of normal saline or complete Freund's adjuvant were repeated once daily during four days. On the fifth day, arthritic rats were treated twice a day with A. ferruginea (100 or $200 \mathrm{mg} / \mathrm{kg}$ ), diclofenac $(3.85 \mathrm{mg} / \mathrm{kg}$ ) or distilled water when normal control group received distilled water. The paw volumes of both sides of hind paws of all animals were recorded with plethysmometer (model 37140 UgoBasile, Italy) before, on day 1 before CFA injection and 1,2, 3 and $4 \mathrm{~h}$ after CFA injection to see the degree of swelling. The volume of paw was measured every 2 days from day 9 to day 21 . The treatment, excepted group 1, was initiated on day 9, when the joints were supposed to be well inflamed. Percentages of inhibition of oedema were obtained for each group as described above.The animals' body weight were recorded before and at the end of the study, on the twenty first day. Rats were killed by decapitation under anesthesia ( $0.5 \mathrm{~mL}$ of valium and $0.25 \mathrm{~mL}$ ketamine) at the end of the study, and blood samples was collected from all groups for hematological analysis and separation of serum for nitrite serum determination. Liver spleen and kidney sample were collected and then homogenized (20\%) in Tris-Hcl buffer $(50 \mathrm{mM}, \mathrm{pH} 7.4)$ at $4^{\circ} \mathrm{C}$ to measure reduce glutathione (GSH), nitrites, catalase (CAT), proteins, superoxide dismutase (SOD), and malondialdéhyde (MDA) within 12 to $24 \mathrm{~h}$.

\section{Biochemical analysis}

The total protein content was determined by the method of Buiret as described by Gornal et al. ${ }^{[24]}$ The glutathione (GSH) content was estimated by the method of Ellman. ${ }^{[25]}$ The superoxyde dismutase (SOD) activity in the tissues was determined by the method described of Misra and Fridovish ${ }^{[26]}$ and the catalase content was estimated by the method of Sinha ${ }^{[27]}$ The malondialdehyde (MDA) content in tissue was determined by the method of Wilbur et al. ${ }^{\text {[28] }}$ The nitrites levels were estimated by the method of Slack. ${ }^{[29]}$

\section{Ethics}

The experimental protocol was in conformity with guidelines of the Cameroon National Ethical Committee on the use of laboratory animals for scientific research (CEEC Council 86/609).

\section{Statistics}

The values are expressed as Mean \pm SEM. The data were analyzed by one way ANOVA followed by Dunnett's test using Graph pad prism (5.03) software. $\mathrm{P}$ values less than 0.05 were considered statistically significant.

\section{Results}

\section{Phytochemical analysis}

Phytochemical analysis of the aqueous extract of A. ferruginea stem bark showed that it contain polyphenols, flavonols, flavonoids, vitamin $\mathrm{C}$ and alkaloids. Total flavonols represented $0.12 \pm 0.04 \mathrm{mg}$ equivalent of quercetin per gram of dried extract. Total phenol content was $58.69 \pm 0.65 \mathrm{mg}$ of caffeic acid per gram of dried extract. Total flavonoids content was $0.18 \pm 0.01 \mathrm{mg}$ equivalent of quercetin per gram of dried extract. Total alkaloids was $27.45 \pm 0.14 \mathrm{mg}$ equivalent of berberine per gram of dried extract and vitamin $C$ represented $0.43 \pm 0.03 \mathrm{mg}$ equivalent of vitamin $\mathrm{C}$ per gram of dry extract (Table 1 ).

Table 1: Phytochemical of Albizia ferruginea the stem bark aqueous extract

\begin{tabular}{|c|c|c|c|c|c|}
\hline Albiziaferruginea & $\begin{array}{c}\text { Polyphenols } \\
\text { (mg CA/g of dry } \\
\text { extract) }\end{array}$ & $\begin{array}{c}\text { Flavonols } \\
\text { (mg QT/g of dry } \\
\text { extract) }\end{array}$ & $\begin{array}{c}\text { Flavonoïds } \\
\text { (mg QT/g of dry } \\
\text { extract) }\end{array}$ & $\begin{array}{l}\text { Ascorbic acid } \\
\text { (mg VC/g of dry } \\
\text { extract) }\end{array}$ & $\begin{array}{c}\text { Alkaloïds } \\
\text { (mg BER/g of dry } \\
\text { extract) }\end{array}$ \\
\hline Quantity & $58.69 \pm 0.65$ & $0.12 \pm 0.04$ & $0.18 \pm 0.01$ & $0.43 \pm 0.03$ & $27.45 \pm 0.14$ \\
\hline
\end{tabular}

The results are expressed as mean $\pm S E M(n=3)$. $C A=$ caffeic acid, $Q T=$ quercetin, $B E R=$ berberine, VC= vitamine $C$.

Effects of the aqueous extract of Albizia ferruginea on cotton pellet-induced granuloma

The weight of the granuloma tissue of the control group was $152.16 \pm 1.48 \mathrm{mg}$ (figure 1). Treatment with aqueous extract of $A$. ferruginea inhibited in a dose dependent manner the proliferation of granulomatous tissues. At the doses of 100 and $200 \mathrm{mg} / \mathrm{kg}$, the granuloma weight decreased to $88.72 \pm 0.81 \mathrm{mg}$ and $82.02 \pm 0.74$ $\mathrm{mg}$, respectively. Implantation of cotton pellet also causes transudation of fluid from neighboring tissues estimated at $494.37 \pm$ $4.40 \mathrm{mg}$. The effects of aqueous extract (100 and $200 \mathrm{mg} / \mathrm{kg}$ ) on the transudative phase were significantly different compare to control. These inhibitory effect were $41.70 \%$ and $46.10 \%$, respectively, compared to control. Diclofenac $(3.85 \mathrm{mg} / \mathrm{kg})$ also significantly inhibited $(p<0.001)$ proliferation of granulomatous tissues by $58.72 \%$ and transudation by $52.59 \%$. 


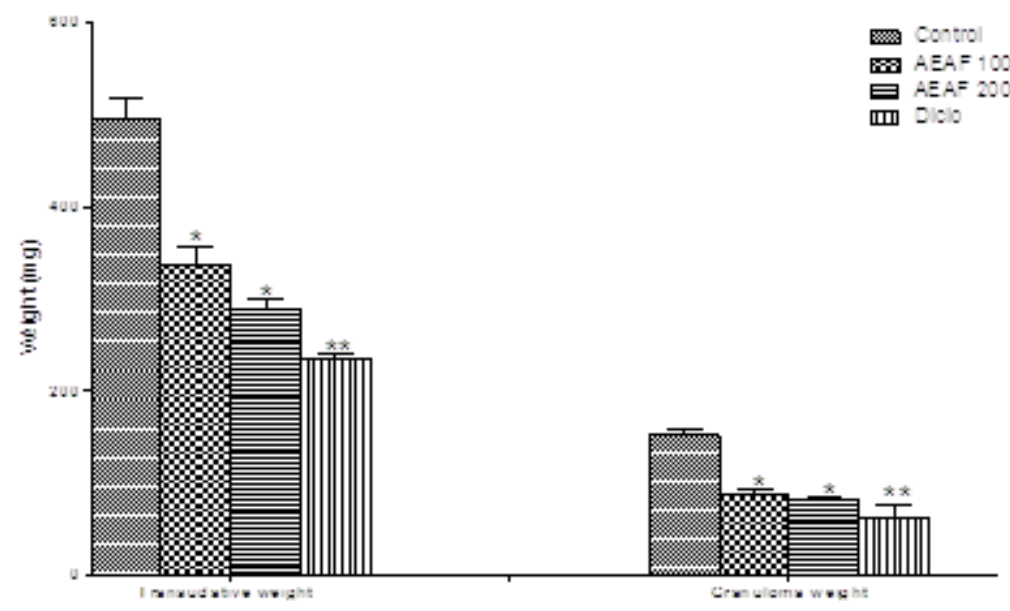

Fig.1: Effects of Albizia ferruginea aqueous extract on wet and dry weight of cotton pellets

Data are expressed as mean \pm SEM, $\mathrm{n}=5 ; * * \mathrm{p}<0.01$, ***p $<0.001$, compared to control group (distilled water). Aq ext 100 or $200=$ aqueous extract of A. ferruginea at the dose of 100 or $200 \mathrm{mg} / / \mathrm{kg}$.

Effects of the aqueous extract of Albizia ferruginea on formalin-induced paw oedema

Subplantar injection of formalin induced œdema, which increased progressively and reached a maximum value of $5.01 \pm 0.06 \mathrm{~mL}, 5$ days after induction. Administration of A. ferruginea $(100 \mathrm{mg} / \mathrm{kg})$ failed to reduce significantly œdema induced by formalin. At the dose of $200 \mathrm{mg} / \mathrm{kg}$ the aqueous extract significantly reduced œdema from day four till the end of the study. The higher inhibition percentage $(25.79 \%)$ was recorded on the seventh day. Diclofenac inhibited $(p<0,001)$ adema induced by formalin compared to control. The maximal inhibition (34.26\%) was recorded on the fifth day after induction of inflammation (figure 2).

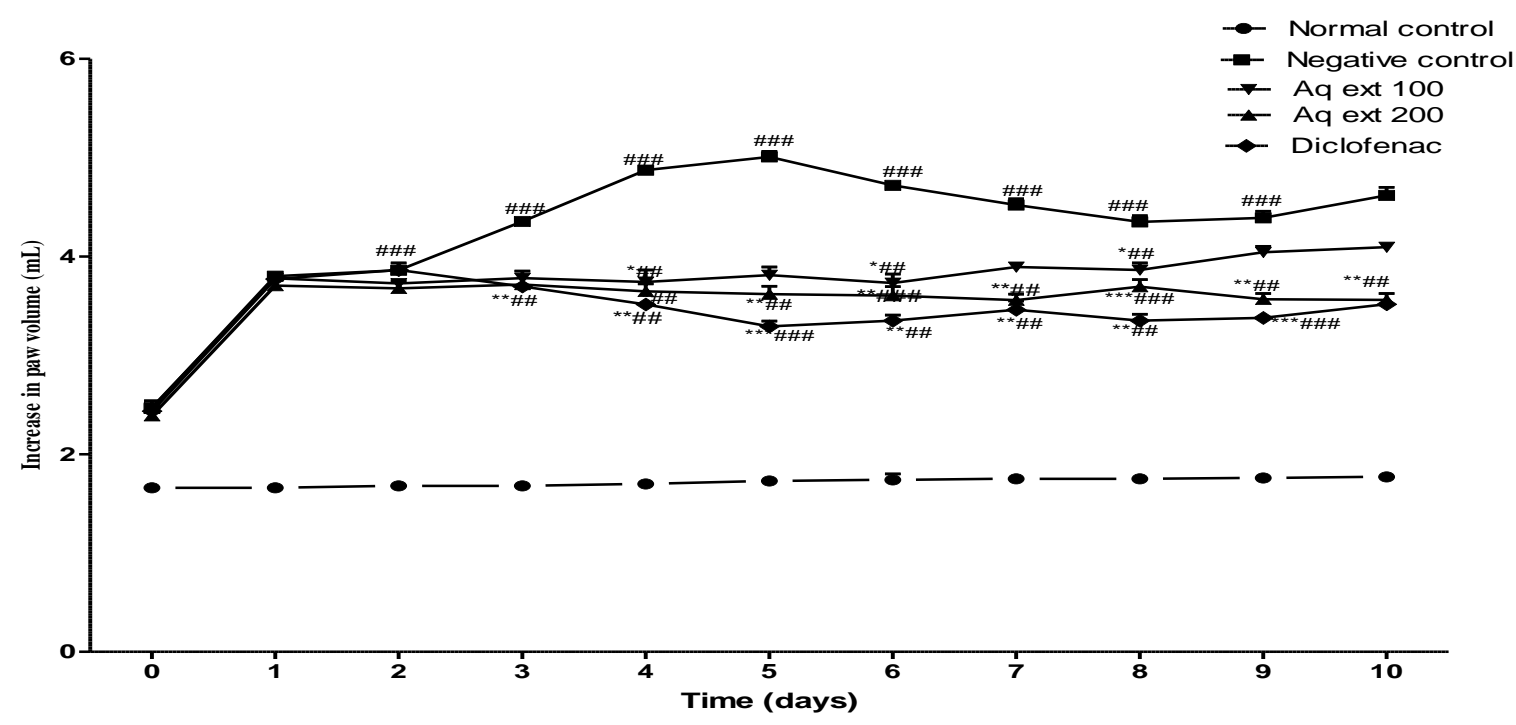

Fig. 2: Effects extracts of Albizia ferruginea on formalin-induced paw odema

Data are expressed as mean \pm SEM, $\mathrm{n}=5 ;{ }^{\#} \mathrm{p}<0.05,{ }^{\# \#} \mathrm{p}<0.01,{ }^{\# \#} \mathrm{p}<0.001$, compared to normal control group, ${ }^{*} \mathrm{p}<0.05,{ }^{* *} \mathrm{p}<0.01$, compared to arthritic control group. Aq ext 100 or $200=$ aqueous extract of $A$. ferruginea at the dose of $100 \mathrm{or} 200 \mathrm{mg} / \mathrm{kg}$.

Table 2: Effect of Albizia ferruginea extract on injected right hindpaw

\begin{tabular}{|c|c|c|c|c|c|c|c|c|}
\hline \multirow[t]{2}{*}{ Treatment } & \multirow[t]{2}{*}{$\begin{array}{c}\text { Doses } \\
(\mathrm{mg} / \mathrm{kg})\end{array}$} & \multicolumn{7}{|c|}{$\begin{array}{l}\text { (odema } \Delta V \text { in } m L) \\
\text { (\% Inhibition of paw oedema) }\end{array}$} \\
\hline & & J9 & $\mathrm{J} 11$ & $\mathrm{~J} 13$ & $\mathrm{~J} 15$ & $\mathrm{~J} 17$ & J19 & $\mathrm{J} 21$ \\
\hline $\begin{array}{l}\text { Normal } \\
\text { control }\end{array}$ & & 0.06 & 0.07 & 0.08 & 0.09 & 0.10 & 0.12 & 0.14 \\
\hline $\begin{array}{c}\text { Arthritic } \\
\text { Control }\end{array}$ & $10 \mathrm{~mL} / \mathrm{kg}$ & $3.06 \pm 0.03 \# \#$ & $3.07 \pm 0.03 \# \#$ & $3.10 \pm 0.04 \# \#$ & $3.2 \pm 0.04 \# \# \#$ & $3.19 \pm 0.11 \# \#$ & $3.07 \pm 0.04 \# \#$ & $3.02 \pm 0.10 \# \#$ \\
\hline $\begin{array}{l}\text { Albiziaferr } \\
\text { uginea } \\
\text { (aqueous) }\end{array}$ & 100 & $\begin{array}{c}2.78 \pm 0.03 \# \# \\
(15.16)\end{array}$ & $\begin{array}{l}2.79 \pm 0,03 \# \# * \\
\quad(32.82)\end{array}$ & $\begin{array}{l}2.78 \pm 0.01 \# \# \\
(20.88)\end{array}$ & $\begin{array}{c}3.00 \pm \\
0.02 \# \# * \\
(35.81)\end{array}$ & $\begin{array}{c}2.98 \pm 0.02 \$ \$ \\
\# \# * \\
(36.64)\end{array}$ & $\begin{array}{l}2.88 \pm 0.01 \# \# \\
(25.46)\end{array}$ & $\begin{array}{l}2.76 \pm 0.01 \# \# \\
\quad(27.29)\end{array}$ \\
\hline
\end{tabular}


International Journal of Innovative Research in Medical Science (IJIRMS)

Volume 03 Issue 09 Sept. 2018, ISSN: 2455-8737, Imp. Factor - 4.102

Available online at - $\underline{w w w . i j i r m s . i n}$

\begin{tabular}{|c|c|c|c|c|c|c|c|c|}
\hline & 200 & $\begin{array}{c}2.60 \pm 0.01 \# * \\
(33.71)\end{array}$ & $\begin{array}{c}2.67 \pm 0.04 \# * * \\
(44.44)\end{array}$ & $\begin{array}{c}2.66 \pm 0.02 \# * \\
(33.13)\end{array}$ & $\begin{array}{c}2.90 \pm \\
0.03 \# \# * * \\
(44.02)\end{array}$ & $\begin{array}{c}2.85 \pm 0.04 \# \# \\
* * \\
(47.40)\end{array}$ & $\begin{array}{c}2.75 \pm 0.1 \#^{*} \\
(37.56)\end{array}$ & $\begin{array}{c}2.65 \pm 0.05 \# * \\
\quad(38.27)\end{array}$ \\
\hline Diclofenac & 3.85 & $\begin{array}{c}2.44 \pm 0.01 \# \# \\
* * \\
(50.58)\end{array}$ & $\begin{array}{c}2.57 \pm 0.02 \# \# * \\
* \\
(54.36)\end{array}$ & $\begin{array}{c}2.46 \pm 0.01 \# \# * \\
* \\
(53.81)\end{array}$ & $\begin{array}{c}2.60 \pm \\
0.03 \# \# * * \\
(69.98)\end{array}$ & $\begin{array}{c}2.60 \pm 0.03 \# \# \\
\# * * \\
(69.08)\end{array}$ & $\begin{array}{c}2.50 \pm 0.02 \# \# * \\
* \\
(61.77)\end{array}$ & $\begin{array}{c}2.42 \pm 0.02 \# \# \\
* * \\
(61.60)\end{array}$ \\
\hline
\end{tabular}

Each value represents mean $\pm S E M, n=5 ; \# p<0.05, \# \# p<0.001$, compared to normal control group, ${ }^{*} p<0.05, * * p<0.01$, compared to arthritic control group.

Effect of Albizia ferruginea aqueous extract on inflammation induced by Complete Freund's adjuvant in rat hindpaw

Table 2 shows the results of aqueous extract of Albizia ferruginea on the swelling of injected paw which is the primary response to the injection of Complete Freund's adjuvant (CFA). Injection of CFA caused a paw œdema that increased progressively to reach a maximal value of $3.20 \pm 0.04 \mathrm{~mL}$, on the $15^{\text {th }}$ day after induction. The œdema of the animals treated with A. ferruginea aqueous extract $(200 \mathrm{mg} / \mathrm{kg})$ and diclofenac $(3.85 \mathrm{mg} / \mathrm{kg})$ group began to subside gradually $(\mathrm{p}<0.001)$ when compared with arthritic control. This primary response to CFA was inhibited by the A. ferruginea aqueous extract in a dose-dependent manner. The effect of $A$. ferruginea aqueous extract (100 or $200 \mathrm{mg} / \mathrm{kg}$ ) was significantly different from arthritic control. The maximal inhibition was 47.40 $\%$ registered on the $17^{\text {th }}$ day following CFA injection. Administration of diclofenac $(3.85 \mathrm{mg} / \mathrm{kg})$ significantly reduced the œdema induced by CFA from the $9^{\text {th }}$ day till the end of the study. The maximal effect of diclofenac was $69.98 \%$ observed on the $15^{\text {th }}$ day after induction of inflammation.

\section{Effect of Albizia ferruginea extract on non-injected left hind} paw

The latent response to the CFA injection was registered on the left hind paw of arthritic rats (Table 3 ). This response which occurred few days after induction was characterized by joint swelling and nodule formation in the contralateral left hind and was significantly different to normal control from the $9^{\text {th }}$ day. Administration of $A$. ferruginea extract (100 or $200 \mathrm{mg} / \mathrm{kg}$ ) protects in a dose dependent manner against contralateral joint swelling compared to arthritic rats. These effects were significant $(p<0.05)$ from day 11 to 17 with a maximal inhibition of $36.16 \%$ on the 17 day. Diclofenac $(3.85 \mathrm{mg} / \mathrm{kg})$ significantly reduces the secondary response to CFA injection.

Table 3: Effect of Albizia ferruginea extract on non-injected left hind paw

\begin{tabular}{|c|c|c|c|c|c|c|c|c|}
\hline \multirow[t]{2}{*}{ Treatment } & \multirow[t]{2}{*}{$\begin{array}{c}\text { Doses } \\
(\mathrm{mg} / \mathrm{kg})\end{array}$} & \multicolumn{7}{|c|}{$\begin{array}{c}\text { (oedema } \Delta V \text { in } m L) \\
\text { (\% Inhibition of paw aedema) }\end{array}$} \\
\hline & & J9 & J11 & J13 & $\mathrm{J} 15$ & $\mathrm{~J} 17$ & J19 & $\mathrm{J} 21$ \\
\hline $\begin{array}{l}\text { Normal } \\
\text { control }\end{array}$ & $10 \mathrm{~mL} / \mathrm{kg}$ & $0.07 \pm 0.04$ & $0.07 \pm 0.01$ & $0.08 \pm 0.11$ & $0.09 \pm 0,05$ & $0.10 \pm 0.01$ & $0.12 \pm 0.01$ & $0.14 \pm 0.04$ \\
\hline $\begin{array}{l}\text { Arthritic } \\
\text { Control }\end{array}$ & $10 \mathrm{~mL} / \mathrm{kg}$ & $0.66 \pm 0.03_{\text {\#\# }}$ & $0.72 \pm 0.05_{\text {\# }}$ & $0.69 \pm 0.03_{\text {\#\# }}$ & $0.79 \pm 0.10_{\text {\#\# }}$ & 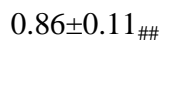 & $0.77 \pm 0.10_{\text {\#\# }}$ & $0.76 \pm 0.10_{\# \#}$ \\
\hline \multirow{2}{*}{$\begin{array}{l}\text { Albizia } \\
\text { ferruginea } \\
\text { (aqueous) }\end{array}$} & 100 & $\begin{array}{l}0.39 \pm 0.12 \\
(08.94)\end{array}$ & $\begin{array}{l}0.45 \pm 0.02 \\
(09.40)\end{array}$ & $\begin{array}{c}0.41 \pm 0.02 \\
(09.70)\end{array}$ & $\begin{array}{l}0.52 \pm 0,03 \\
\quad(13.06)\end{array}$ & $\begin{array}{c}0.58 \pm 0.02 \\
(19.27)\end{array}$ & $\begin{array}{l}0.50 \pm 0.02 \\
(12.69)\end{array}$ & $\begin{array}{l}0.48 \pm 0.02 \\
(11.84)\end{array}$ \\
\hline & 200 & $\begin{array}{c}0.36 \pm 0.02 \\
(12.54)\end{array}$ & $\begin{array}{l}0.36 \pm 0,03 \\
(21.10)\end{array}$ & $\begin{array}{l}0.37 \pm 0.01 \\
(14.95)\end{array}$ & $\begin{array}{c}0.40 \pm 0,05_{\text {\#\# }} \\
(27.78)\end{array}$ & $\begin{array}{l}0.43 \pm 0,01_{\text {\#\# }} \\
(36.16)\end{array}$ & $\begin{array}{c}0.46 \pm 0,02 \\
(17,61)\end{array}$ & $\begin{array}{c}0.44 \pm 0.02 \\
(17.39)\end{array}$ \\
\hline Diclofenac & 3.85 & $\begin{array}{c}0.27 \pm 0.04_{\# \#}{ }^{* * *} \\
(55.44)\end{array}$ & $\begin{array}{c}0.20 \pm 0,02_{\# \#} \\
(57.87)\end{array}$ & $\begin{array}{c}0.16 \pm 0.02^{\# \# *} \\
(58.68)\end{array}$ & $\begin{array}{c}0.12 \pm 0.03 \#^{* *} \\
(62.04)\end{array}$ & $\begin{array}{c}0.18 \pm 0.04_{\# \# *} \\
* \\
(66.49)\end{array}$ & $\begin{array}{c}0.20 \pm 0.03_{\# \#}^{*} \\
* \\
(59.84)\end{array}$ & $\begin{array}{c}0.19 \pm 0.02_{\# \#}^{*} \\
* \\
(55.22)\end{array}$ \\
\hline
\end{tabular}

Each value represents mean $\pm S E M, n=5 ;{ }^{\#} p<0.05,{ }^{\# \#} p<0.001$, compared to normal control group, ${ }^{* *} p<0.01$, compared to arthritic control group.

Table 4: Effect of Albizia ferruginea extract on body weight of arthritis rats

\begin{tabular}{lccc}
\hline Treatment & \multicolumn{2}{c}{ Body weight \pm ESM (g) } & \% increase in body weight \\
\cline { 2 - 3 } & Initial & Final & \\
\hline Normal control & $205.70 \pm 0.17$ & $234.61 \pm 1.17$ & 14.04 \\
Arthritic control & $205.64 \pm 1.37$ & $218.78 \pm 2.473^{\# \#}$ & 6.37 \\
AEAF $100 \mathrm{mg} / \mathrm{kg}$ & $205.78 \pm 0.40$ & $228.04 \pm 2.39^{*}$ & 10.84 \\
AEAF $200 \mathrm{mg} / \mathrm{kg}$ & $205.32 \pm 0.37$ & $231.17 \pm 0.50^{*}$ & 12.40 \\
Diclofenac $(3.85 \mathrm{mg} / \mathrm{kg})$ & $205.44 \pm 0.91$ & $225.16 \pm 1.19^{\# *}$ & 8.67
\end{tabular}

Each value represents mean $\pm S E M, n=5 ;{ }^{\#} p<0.05,{ }^{\#} p<0.001$, compared to normal control group, ${ }^{*} p<0.05$, compared to arthritic control group. 
International Journal of Innovative Research in Medical Science (IJIRMS)

Volume 03 Issue 09 Sept. 2018, ISSN: 2455-8737, Imp. Factor - 4.102

Available online at $-\underline{w w w . i j i r m s . i n}$

Table 5: Effect of Albizia ferruginea extract on hematological profiles of arthritic rats

\begin{tabular}{l|ccccc}
\hline \multirow{2}{*}{ Treatment } & \multicolumn{3}{c}{ Hematological parameters } \\
\cline { 2 - 6 } & WBC $\left(10^{3} / \mu \mathrm{L}\right)$ & Lym $\left(10^{3} / \mu \mathrm{L}\right)$ & $\mathrm{RBC}\left(10^{6} / \mu \mathrm{L}\right)$ & $\mathrm{Hb}(\mathrm{g} / \mathrm{dL})$ & $\mathrm{PLAT}\left(10^{3} / \mu \mathrm{L}\right)$ \\
\hline Normal control & $6.60 \pm 0.62$ & $1.45 \pm 0.21$ & $8.77 \pm 0.16$ & $12.35 \pm 0.79$ & $4.79 \pm 0.75$ \\
Arthritic control & $8.88 \pm 0.04$ & $1.97 . \pm 0.02$ & $6.39 \pm 0.17^{\#}$ & $10.96 \pm 0.51^{\#}$ & $3.46 \pm 0.47^{\# \#}$ \\
AEAF $100 \mathrm{mg} / \mathrm{kg}$ & $6.80 \pm 0.34^{*}$ & $1.73 \pm 1.81^{*}$ & $8.38 \pm 0.35^{*}$ & $11.48 \pm 0.65$ & $4.52 \pm 0.55$ \\
AEAF $200 \mathrm{mg} / \mathrm{kg}$ & $6.72 \pm 0.26$ & $1.75 \pm 1.66$ & $8.69 \pm 0.25$ & $11.55 \pm 0.49$ & $4.66 \pm 0.96$ \\
Diclofenac $3.85 \mathrm{mg} / \mathrm{kg}$ & $6.72 \pm 0.33$ & $1.47 \pm 0.29$ & $7.62 \pm 0,44$ & $11.14 \pm 0,74$ & $4.26 \pm 0.50$ \\
\hline
\end{tabular}

Each value represents mean $\pm S E M, n=5 ;{ }^{\#} p<0.05,{ }^{\# \#} p<0.001$, compared to normal control group, ${ }^{*} p<0.05,{ }^{* *} p<0.01$, compared to control group (arthritic rats); WBC=White blood cell;Lym=Lymphocytes; RBC=Red blood cell; Hb=Hemoglobin; .PLAT=Platelets.

Effect of Albizia ferruginea extract on body weight of arthritic rats

An increase in body weight was noted in all groups of animals. $A$. ferruginea extract (100 or $200 \mathrm{mg} / \mathrm{kg}$ ) has improved the growth of treated rats compared to controls groups (Table 4).

Effect of Albizia ferruginea extract on hematological profiles of arthritic rats

The table 5 illustrates hematological profiles of experimental rats. Increase in number of white blood cell and decrease in number of red blood cell were found in arthritic control compare to normal control. A. ferruginea extract $(100 \mathrm{mg} / \mathrm{kg}$ and $200 \mathrm{mg} / \mathrm{kg})$ tend to normalize the level of these parameters. Result also indicates that Diclofenac at $3.85 \mathrm{mg} / \mathrm{kg}$ fell to stabilize the level of red blood cell.

Effect of Albizia ferruginea aqueous extract on biochemical parameters

Effects on tissue level of protein and malondialdehyde

Result shows a significant increase of total protein in liver, kidneys and spleen of arthritic rats. An increasing level of $68.81 \%$ in liver,
$58.72 \%$ in kidney and $52.52 \%$ in spleen was recorded at the end of the experiment compared to arthritic control. Treatment with $A$. ferruginea aqueous extract at the doses of 100 or $200 \mathrm{mg} / \mathrm{kg}$ caused a reduction of the total protein in these tissues. The effect of aqueous extract was significant $(\mathrm{p}<0.01)$ in the kidney compared to arthritic rats. Treatment with diclofenac $(3.85 \mathrm{mg} / \mathrm{kg}$ ) normalized the level of total protein in all tissues (figure 3). The level of malondialdehyde was significantly increased in liver, kidney and spleen of animal treated with the Complete Freund's Adjuvant (CFA) compared to normal control (figure 4). Administration of A. ferruginea aqueous extract led to a significant decrease of the MDA level in these tissues. The effect of aqueous extract was dose-dependent. A. ferruginea aqueous extract (200 $\mathrm{mg} / \mathrm{kg}$ ) reduced the MDA level by $40.63 \%, 46.50 \%(\mathrm{p}<0.05)$ and $72.88 \%(\mathrm{p}<0.01)$, respectively in the liver, kidney and spleen compared to arthritic rats. Diclofenac $(3.85 \mathrm{mg} / \mathrm{kg})$ caused a decrease of MDA level by $56.18 \%, 51.07 \%(\mathrm{p}<0.01)$ and $33.88 \%$ $(\mathrm{p}<0.05)$ in the liver, kidney and spleen, respectively, compared to arthritic control.

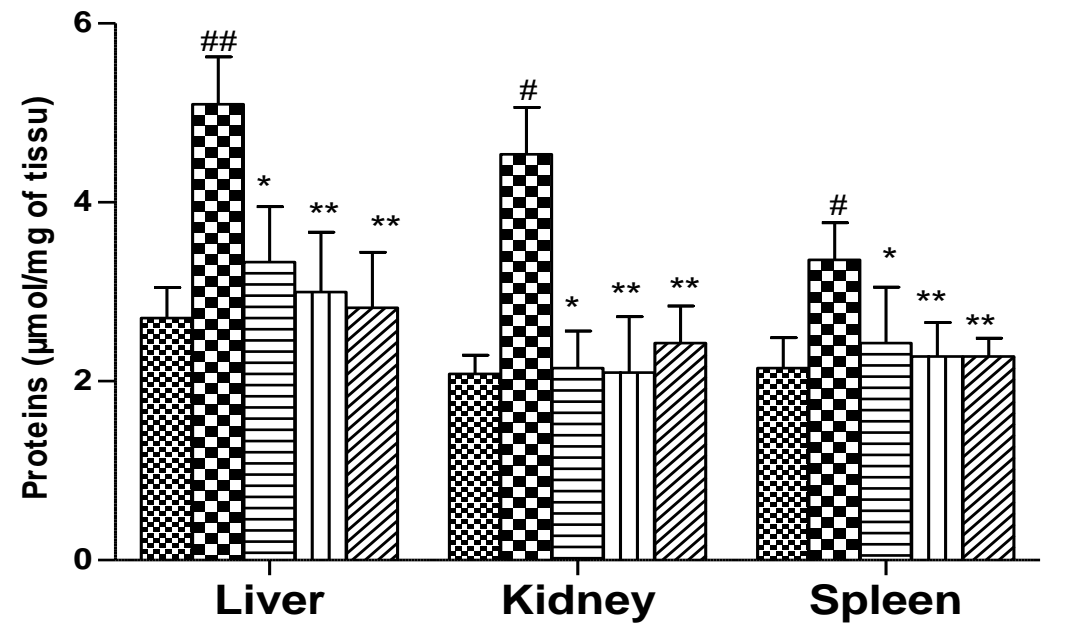

\$ Normal Control

0 arthritic Control

ÆAq ext 100

س. Aq ext 200

שIAs Diclofenac

Fig.3: Effects of aqueous extract of Albizia ferruginea on tissue level of protein

Each value represents mean $\pm \mathrm{SEM}, \mathrm{n}=5 ;{ }^{\#} \mathrm{p}<0.05,{ }^{\# \#} \mathrm{p}<0.001$, compared to normal control group, ${ }^{*} \mathrm{p}<0.05,{ }^{* * *} \mathrm{p}<0.01$, compared to arthritic control group.Aq ext $100=$ aqueous extract of A. ferruginea dose 100; Aq ext $200=$ aqueous extract of A. ferruginea dose 200 


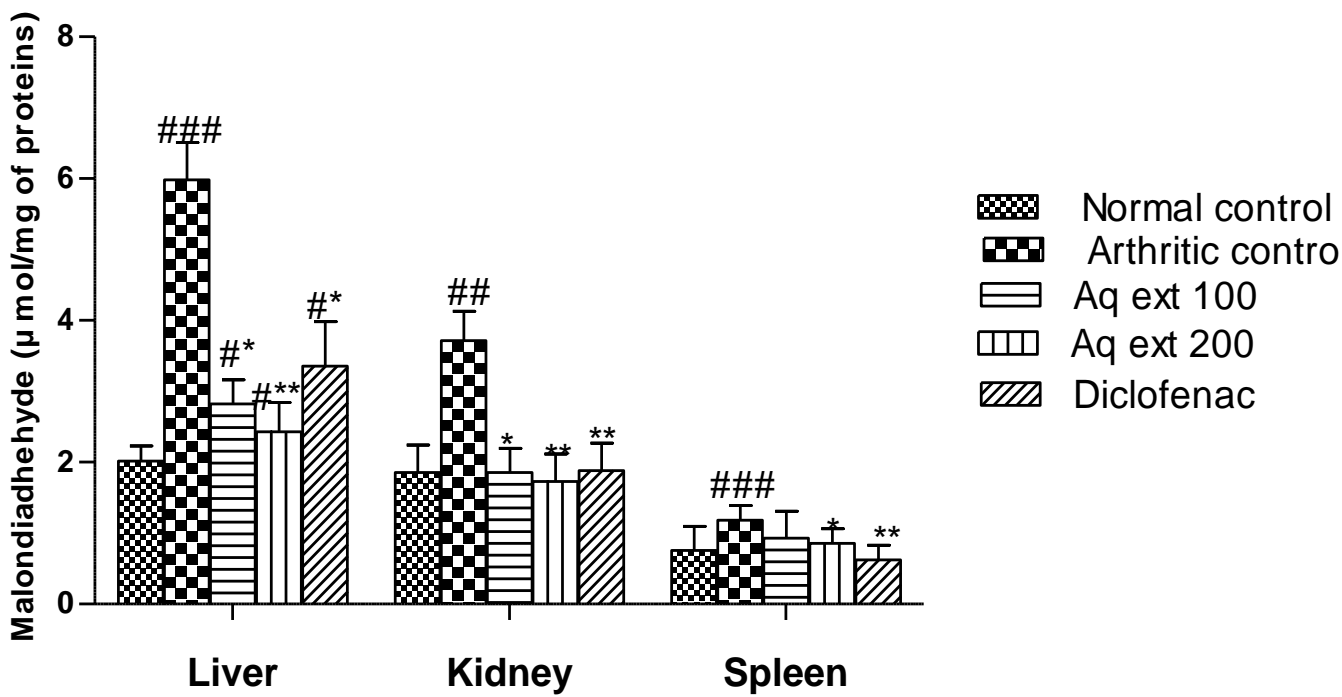

Fig 4: Effects of aqueous extract of Albizia ferrugineaon tissue level of malondialdehyde

Each value represents mean \pm SEM, $\mathrm{n}=5$; ${ }^{\#} \mathrm{p}<0.05,{ }^{\#} \mathrm{p}<0.001$, compared to normal control group, ${ }^{*} \mathrm{p}<0.05,{ }^{* *} \mathrm{p}<0.01$, compared to arthritic control group.Aqext $100=$ aqueous extract of $A$. ferruginea dose 100; Aqext200= aqueous extract of $A$. ferruginea dose 200.

\section{Effects on superoxyde dismutase and catalase activity}

Results indicated a significant decrease of superoxide dismutase (SOD) activity in rat tissue following treatment with complete Freund adjuvant compared to normal control (figure 6). Administration of A. ferruginea (100 and $200 \mathrm{mg} / \mathrm{kg}$ ) causes a dose dependent increase in the SOD activity in rat tissue. In liver, kidney and spleen, the SOD activity increased by $42.72 \%, 60.51 \%$ and $30.86 \%$, respectively, compared to arthritic control. Diclofenac $(3.85 \mathrm{mg} / \mathrm{kg})$ referent substance has increase the SOD activity by
$43.36 \%, 63.31 \%$ and $33.15 \%$ compared with arthritic control animals.

Catalase activity decreased significantly in tissues of animals treated with CFA compared to normal control. In the liver, catalase activity of normal control was $0.80 . \pm 0.05 \mathrm{mmolmin}-1 / \mathrm{mg}$ of protein compared to $0.31 \pm 0.05 \mathrm{mmolmin}^{-1} / \mathrm{mg}$ of protein registered in arthritic group. When treated with $A$. ferruginea aqueous extract at the doses of 100 or $200 \mathrm{mg} / \mathrm{kg}$, catalase activity increased $(\mathrm{p}<0.01)$ in dose dependent manner. This effect was significantly different compared to arthritic group and the maximal effect was $40.94 \%$, $42.03 \%$ and $35.29 \%$, respectively in liver, kidney and spleen. Treatment with diclofenac $(3.85 \mathrm{mg} / \mathrm{kg})$ caused an elevation of the catalase activity by $44.11 \%, 41.17 \%$ and $33.63 \%$, respectively in liver, kidney and spleen, compared to arthritic control (figure 5).

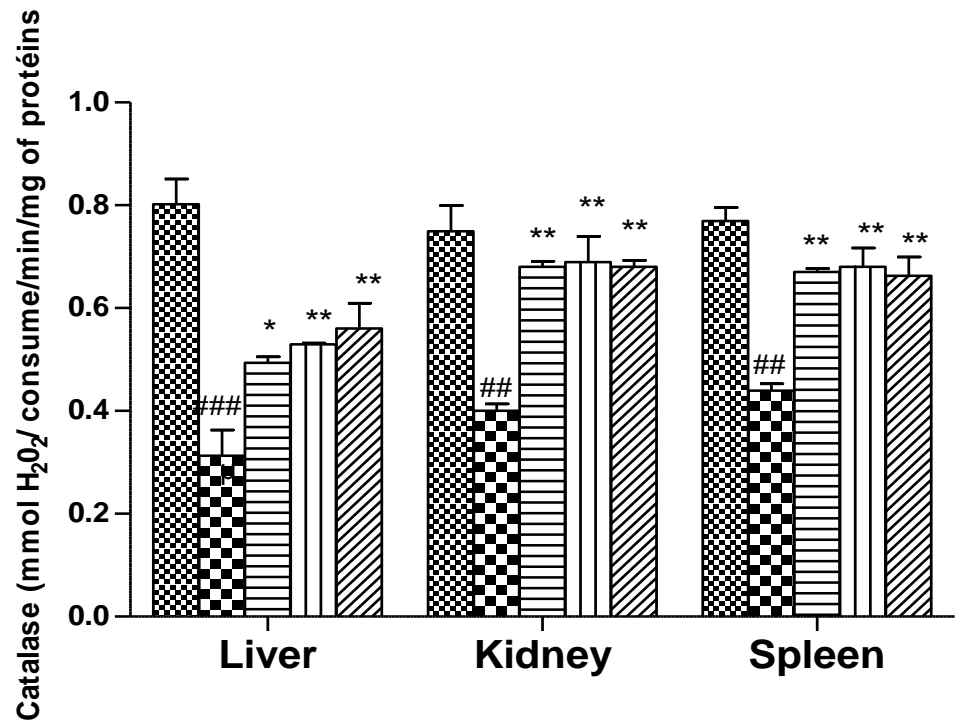

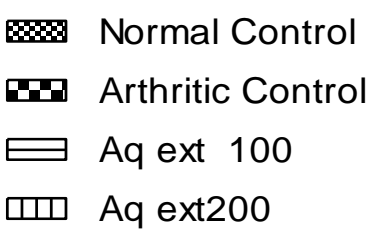

एᄑI Diclofenac

Fig.5: Effects of aqueous extract of Albizia ferruginea on catalase activity

Each value represents mean $\pm \mathrm{SEM}, \mathrm{n}=5 ;{ }^{\#} \mathrm{p}<0.05,{ }^{\# \#} \mathrm{p}<0.001$, compared to normal control group, ${ }^{*} \mathrm{p}<0.05,{ }^{* *} \mathrm{p}<0.01$, compared to arthritic control group.Aq ext 100= aqueous extract of A. ferruginea dose 100; Aq ext 200= aqueous extract of A. ferruginea dose 200. 


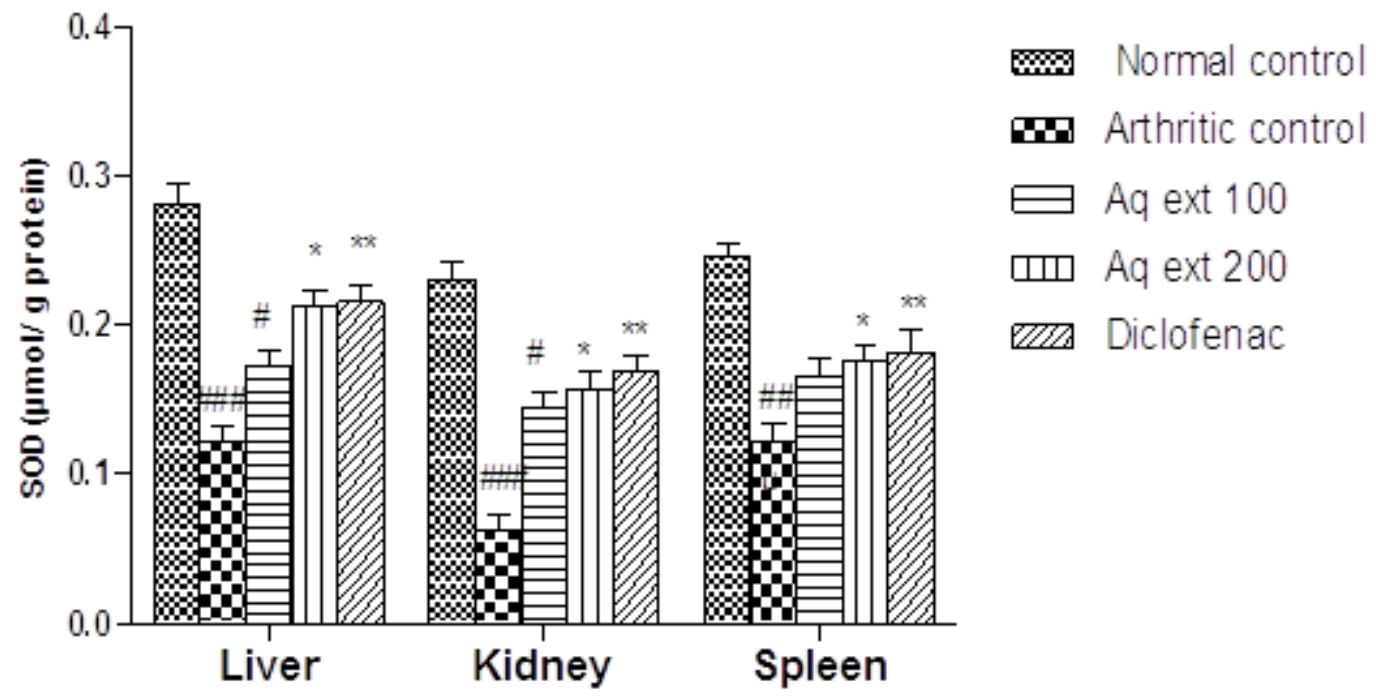

Fig.6: Effects of aqueous extract of Albizia ferruginea on superoxide dismutase activity

Each value represents mean $\pm \mathrm{SEM}, \mathrm{n}=5$; ${ }^{\#} \mathrm{p}<0.05,{ }^{\#} \mathrm{p}<0.001$, compared to normal control group, ${ }^{*} \mathrm{p}<0.05,{ }^{* *}$ p $<0.01$, compared to arthritic control group. Aqext 100= aqueous extract of A. ferruginea dose 100; Aq ext $200=$ aqueous extract of A. ferruginea dose 200.

\section{Effects on tissue level of glutathione}

Treatment of rats with Complete Freund's Adjuvant induced after 21 days, a significant reduction of the level of glutathione in liver, kidney and spleen by $65.92 \%, 50.16 \%$ and $23.25 \%$, respectively, compare to normal control (figure 7). Administration of $A$. ferruginea (100 or $200 \mathrm{mg} / \mathrm{kg}$ ) and diclofenac $(3.85 \mathrm{mg} / \mathrm{kg})$ result in an increase in the level glutathione. The aqueous extract acts in dose dependent manner. The effect of the most effective dose of $A$. ferruginea extract $(200 \mathrm{mg} / \mathrm{kg})$ was comparable to that of diclofenac. The level of glutathione of arthritic rats compared to those treated with $A$. ferruginea extract $(200 \mathrm{mg} / \mathrm{kg}$ ) raised from $0.26 \pm 0.01$ to $0.52 \pm 0.01 \mathrm{mmol} / \mathrm{g}$ of protein in the liver, from $0.31 . \pm 0.01$ to $0.55 \pm 0.01 \mathrm{mmol} / \mathrm{g}$ of protein in the kidney and from $0.76 \pm 0.01$ to $0.91 \pm 0.02 \mathrm{mmol} / \mathrm{g}$ of protein in the spleen.

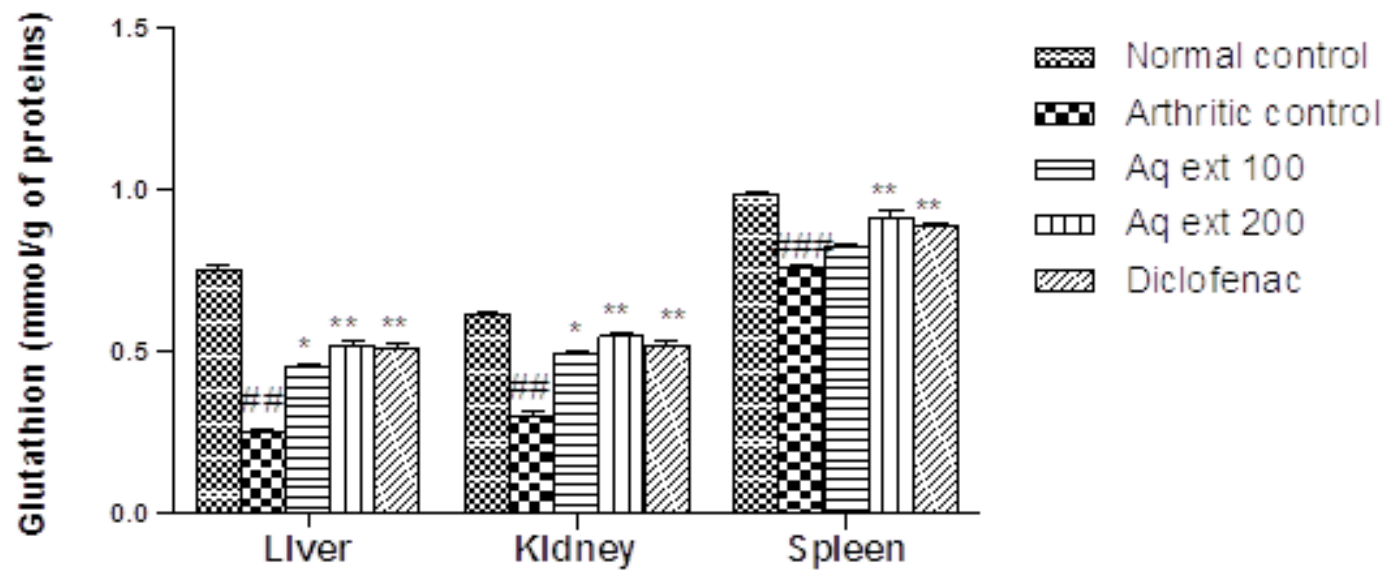

Fig.7: Effects of aqueous extract of Albizia ferruginea on tissue level of glutathione

Each value represents mean $\pm \mathrm{SEM}, \mathrm{n}=5$; ${ }^{\#} \mathrm{p}<0.05,{ }^{\# \#} \mathrm{p}<0.001$, compared to normal control group, ${ }^{*} \mathrm{p}<0.05,{ }^{* *} \mathrm{p}<0.01$, compared to arthritic control group. Aq ext $100=$ aqueous extract of A. ferruginea dose 100; Aq ext $200=$ aqueous extract of $A$. ferruginea dose 200 .

\section{Effects on nitrites level}

A significant increase of serum nitrites level, compared to normal control was noted after treatment of rats with complete Freund adjuvant. This effect was inhibited in a significant manner by administration of $A$. ferruginea aqueous extract (100 and 200 $\mathrm{mg} / \mathrm{kg}$ ). Inhibitory effects were $36.79 \%$ and $39.15 \%$, respectively, compared to arthritic control. Diclofenac also reduce significantly nitrite production induced by CFA (figure 8a). Induction of arthritis by CFA also lead to significant nitrites production in liver, kidney and spleen of animals compared to normal control. Administrated at the doses of 100 and $200 \mathrm{mg} / \mathrm{kg}$, A. ferruginea aqueous extract significantly deceased nitrites production in liver, kidney and spleen by $50.51 \%, 28.48 \%$ and $34.33 \%$, respectively, compared to arthritic control. Diclofenac $(3.85 \mathrm{mg} / \mathrm{kg})$ exhibited $53.35 \%, 30.81 \%$ and $38.24 \%$ of inhibition respectively in the liver, kidney and spleen, compared to arthritic control (figure $8 \mathrm{~b}$ ). 


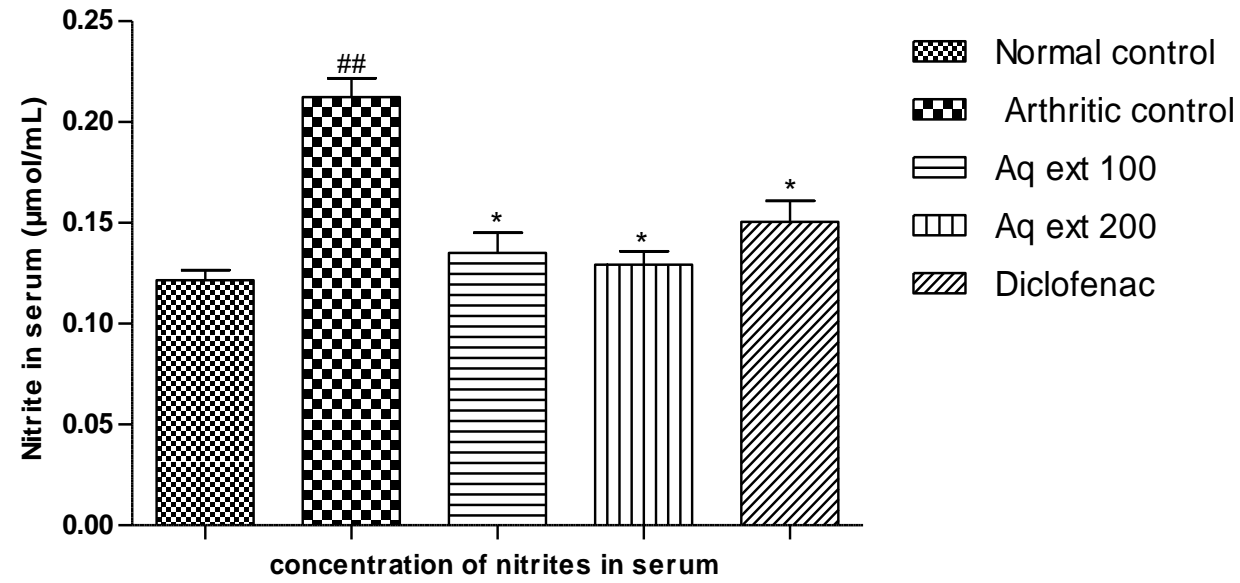

Fig.8a: Effects of aqueous extract of Albizia ferruginea on serum level of nitrites

Each value represents mean $\pm \mathrm{SEM}, \mathrm{n}=5$; ${ }^{\# \#} \mathrm{p}<0.01$, compared to normal control group, ${ }^{\mathrm{p}}<<0.05$, compared to arthritic control group. Aq ext $100=$ aqueous extract of Albizia ferruginea dose 100; Aq ext 200= aqueous extract of Albizia ferruginea dose 200.

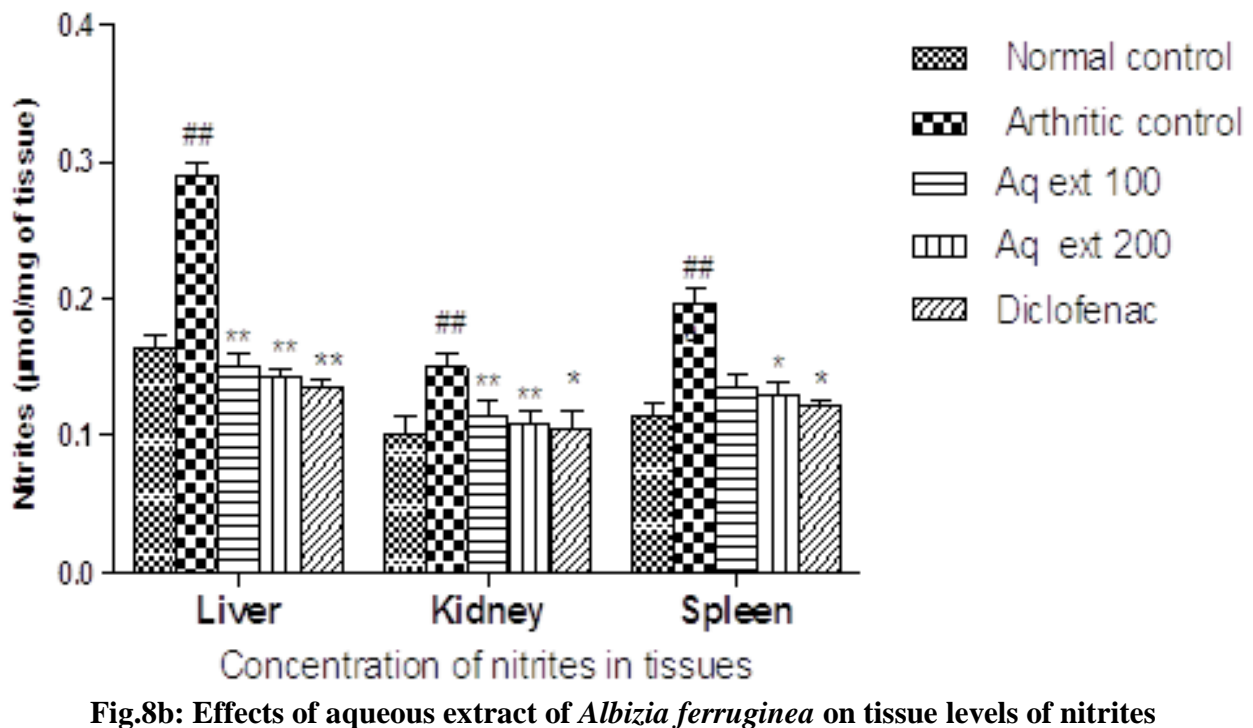

Each value represents mean $\pm \mathrm{SEM}, \mathrm{n}=5 ;{ }^{\#} \mathrm{p}<0.05,{ }^{\# \#} \mathrm{p}<0.001$, compared to normal control group, ${ }^{*} \mathrm{p}<0.05,{ }^{* *} \mathrm{p}<0.01$, compared to arthritic control group. Aq ext 100= aqueous extract of A. ferruginea dose 100; Aq ext 200= aqueous extract of A. ferruginea dose 200.

\section{Discussion}

Chronic inflammation model, induced by subcutaneous implantation of foreign bodies, is used commonly in experimentations. It is the most suitable methods for the evaluation of drugs efficiency against proliferative phase of inflammation. ${ }^{[3]}$ Subcutaneous implantation of the cotton pellet causes granulomatous tissue formation. This granulomatous tissues is due firstly to the accumulation of macrophages, neutrophils and lymphocytes around the foreign particles, which is followed by proliferation of fibroblast cells. ${ }^{[30]}$ The cotton pellet stimulates the immune system to produce interleukins and antibodies that consequently, stimulate proliferation of lymphocytes and accumulation of cells around the pellets to form granulomatous tissue. $^{[31]}$ Thus, inhibition of granulomatous tissue formation indicates an anti-proliferative effect of a drug. The result of this study show that Albizia ferruginea extract (100 or $200 \mathrm{mg} / \mathrm{kg}$ ) inhibited accumulation of cells and substances around the foreign body. This may be due to its anti-proliferative properties.
Transude material is correlated to the wet weight of the cotton pellets. ${ }^{[32]}$ Our result show an inhibiting effect of the aqueous extract of A. ferruginea on the transudative phase of inflammation. This may suggest its antiphlogistic effects. This plant effect was closer to that of diclofenac, a non steroidal anti-inflammatory drugs (NSAID). It is demonstrated that NSAID reduce the size of granuloma and the quantity of transudation through inhibition of pro-inflammatory mediator's production (inflammatory cytokines and on other lipid mediators of inflammation like leukotrienes and prostaglandins), inhibition of cells infiltration (leucocytes) and prevention of fibroblast proliferation and collagen fibres and mucopolysaccharides synthesis. ${ }^{[33,34]}$

The aqueous extract of $A$. ferruginea was further tested on chronic inflammation induced by formalin. It is well known that œema induced by formalin in rats is one of the most suitable investigation to screen anti-arthritic and anti-inflammatory agents, because this inflammation model is similar to human arthritis. Arthritis induced by formalin is used for the evaluation of an eventual anti- 


\section{International Journal of Innovative Research in Medical Science (IJIRMS) Volume 03 Issue 09 Sept. 2018, ISSN: 2455-8737, Imp. Factor - 4.102 \\ Available online at $-\underline{w w w . i j i r m s . i n}$}

proliferative effects of natural substances. ${ }^{[22]}$ In this study, we demonstrated that $A$. ferruginea aqueous extract significantly inhibited formalin induced inflammation. This result in accordance with that of granuloma induced cotton pellet which demonstrated anti-proliferative and antiarthritic properties of this plant extract. Previous study proved that, chronic inflammation induced by formalin results from cell damage which induces production of endogenous mediators such as histamine, serotonin, prostaglandins, and bradykinin. ${ }^{[35]}$ Therefore, it may be suggest that A. ferruginea extract should be involved in the inhibition of the production and/or the activities of these inflammatory mediators. These result corroborate previous study on the effects of the stem bark of aqueous extract of A. ferruginea on inflammation induce in rat's paw by carrageenan, dextran, serotonin and histamine.

The most study chronic model of inflammation is the arthritis induced by a complete Freund's adjuvant. One of the reasons justifying the wide exploitation of this model is the strong correlation existing between the efficacy of therapeutic agents on this model and on the human's rheumatoid arthritis. Moreover, Freund's adjuvant-induced arthritis is a very rapid erosive disease. ${ }^{[36]}$ The first reaction after injection of Freund's adjuvant heat killed (Mycobacterium tuberculosis in paraffin oil) which is due to irritant effects of the adjuvant is the soft tissue thickening at the depot site. This initial response is followed by an immunologic events. $^{[37]}$

Dudhgaonkar et al ${ }^{[38]}$ demonstrated that after CFA injection ina rat hind paw induces a primary response characterized by swelling and hyperalgesia of the injected paw. This reaction is followed by a delayed systemic response which occurs few days later on the controlateral paw and characterized by joint swelling and nodule formation in the tail.

In this present study, both initial and delayed responses were observed after injection of a complete Freund' adjuvant. Treatment of rats with A. ferruginea extracts significantly reduce oedema of the injected paw compared to arthritic rats. This extract also inhibits the delayed hypersensitive response which is a latent secondary systemic response occurring few days on the controlateral paw, by preventing significant increase in right paw oedema as compared to normal rats, thus indicating it antiinflammatory effect.

Arthritis induced by CFA is characterized by a reduction of body weight and It is showed that the loss of body weight observed in this case is associated with higher production of pro-inflammatory cytokines like inter-leukin- 1 and tumor necrosis factor- $\alpha .^{[37,39]}$ Result from our study confirmed this hypothesis and revealed a better improvement effect of $A$. ferruginea extract compared to that of diclofenac, on the body weight of rats within the experimental period. This observation suggest that antiarthritic effect of $A$. ferruginea aqueous extract could be due to it inhibitory effect on the release of pro-inflammatory cytokines.

Tissue damage is related to membrane lesion and impairment of the membrane permeability due to lipid peroxidation. Lipid peroxidation is assessed through determination of the malondialdehyde level (MDA). Our result showed that, administration of CFA resulted in a significant increase in the level of MDA in the tissues of arthritic rats. Treatment with aqueous extract of A. ferruginea significantly decreased the MDA levels. This activity could be due to an anti-oxidative effect of this plant extract.

The earliest cells of the immunological system that contribute to the defense of the body against pathogens are neutrophils. However, the activity of these immune cells may lead to tissue damages in chronic inflammatory diseases. Interaction between neutrophils and other components like resident cells, local inflammatory mediators and extracellular matrix at the site of the inflammation induces liberation of degrading enzymes, reactive oxygen and nitrogen species as well as additional inflammatory mediators which increase inflammatory process especially through oxidative stress. ${ }^{[2]}$ Chronic inflammation induced either by CFA causes oxidative stress and damage to several organs including the liver, ${ }^{[40]}$ the kidney ${ }^{[41]}$ and the spleen. ${ }^{[42]}$ Endogenous enzymes such as superoxide dismutase (SOD), catalase (CAT) and glutathione peroxidase are involve in the protection against free radical induced tissue damages cause by the superoxide anion $\left(\mathrm{O}^{2-}\right)$ and hydrogen peroxide $\left(\mathrm{H}_{2} \mathrm{O}_{2}\right){ }^{[43]}$ Glutathione peroxidase degrade the organic hydroperoxydes and hydrogen peroxide into harmless compounds by using reduced glutathione (GSH) as a substrate. The aqueous extract of $A$. ferruginea significantly increased the levels of SOD and the activities of CAT and GSH suggesting it antioxidative effect.

It has also been established that CFA could activates of the inducible NO-synthase for massive production of nitric oxide. Nitrite is a stable product of NO which is a mediator of inflammation involving in the synthesis of prostaglandins, cytokines and reactive oxygen species. ${ }^{[44,45]}$ The result of this study showed the inhibitory effect of $A$. ferruginea aqueous extract on the inducible NO-synthase activity, corroborating the antioxidative activity of this plant extract.

The phytochemical analysis of the aqueous extract of A. ferruginea stem backs shows that it contains compounds like polyphenols, flavonoids, flavonols, alkaloids and ascorbic acid. These compound have extensive pharmacological effects such as antioxidant, inhibition of platelet aggregation and antiinflammatory. ${ }^{[46]}$ Previous study has shown that ascorbic acid is an antioxidant that reduces lipid peroxidation directly or indirectly through regeneration of vitamins $\mathrm{E},{ }^{[47]}$ or by binding free radicals species via a transfer of electron with a view to protect biological membranes from peroxide damage. ${ }^{[48]}$ It is demonstrated that, ascorbic acid could normalize the level of malondialdehyde, potentiate the activities of superoxide dismutase. ${ }^{[49]}$

Flavonoids possess an antioxidant property which confers to this important class of compound a potential anti-inflammatory effects. ${ }^{[50]}$ Study showed that flavonoids inhibit production of lipid derivative inflammatory mediators such as prostaglandins, leukotrienes through inhibition of their substrate or their catalytic enzyme. ${ }^{[50,51]}$ Flavonoids inhibit neutrophil degranulation and reduce complement activation. ${ }^{[48]}$ It has been reported that polyphenols may inhibit lipid peroxidation and enzymes involve in the degradation of the arachidonic acid into inflammatory mediators. ${ }^{[52]}$ The effect of the A. ferruginea extract may be partly related to the presence of these compounds. Nevertheless, further study are require to understand the mechanism of the A. ferruginea aqueous extract on inflammatory diseases. 


\section{Conclusion}

The results of the present study show that the aqueous extract of $A$. ferruginea possesses an anti-inflammatory effect. A. ferruginea aqueous extract inhibits transudative and proliferative phases of cotton pellet induced granuloma. This extract also reduces oedema induced by formalin and complete Freund's adjuvant. These antiinflammatory effects of the aqueous bark extract of A. ferruginea on chronic inflammation may be due to its inhibitory effect on proinflammatory mediators and its antioxidant properties. These findings therefore supporting the use of the stem bark of this plant in the folk medicine for the treatment of anti-inflammatory diseases. A. ferruginea could be a potential source of new antiinflammatory compounds. Thus, further studies are needed to assess the possible activities on joint destruction causes by arthritis and to evaluate the safety of this extract.

\section{Acknowledgments}

Thanks to Madam ATEGA Therese, a traditherapeut that guided us for the choice of the plant. We are also grateful for all those who give us a help during this study. The authors are also thankful to Prof. Pieme Constant, Biology and Pharmacology Laboratory, Department of Biochemistry of Faculty of Medecine and Biomedicals Sciences of Yaounde for providing laboratory facilities to conduct a part of the research work and Pr. Alain Bertrand Dongmo of Department of Animal Biology, Faculty of Science, University of Douala, Cameroon, helped of material (plethysmometer, model 37140 UgoBasile, Italy).

\section{Abbreviations}

A.ferruginea = Albizia ferruginea $\mathrm{CA}=$ caffeic acid, $\mathrm{QT}=$ Quercetin, $\mathrm{BER}=$ berberine, $\mathrm{VC}=$ vitamine $\mathrm{C}$; GSH: Glutathione; SOD: Superoxyde dismutase, CAT: Catalase; MDA: Malondialdehyde.

\section{References}

[1] Yoon-Hee CC, In-Kwon C, Woo-Hyun L, Hyeung-Sik, Sae-Kwang K.Effect of DHU001, a polyherbal formula on formalin-induced paw chronic inflammation of mice. Toxicological Research, 2011;27: 95-102.

[2] Anosike CA, Obidoa O, Ezeanyika LUS. Membrane stabilization as a mechanism of the anti-inflammatory activity of methanol extract of garden egg (Solanumaethiopicum). DARU Journal of Pharmaceutical Sciences, 2012; 20:76-80.

[3] Sunita P, Jha S, Pattanayak SP. Anti-inflammatory and in-vivo antioxidant activities of Cressa cretica Linn., a halophytic plant, Midddle-East Journal of Scientific Research, 2011; 8: 129-140.

[4] Delaporte RH, Sanchez GM, Cuellar AC. Antiinflammatory activity and lipid peroxidation inhibition of iroidlamiide isolated from Boucheafluminensis (Vell.) Mold. (Verbenaceae). Journal of Ethnopharmacology, 2002;82: 127-130.

[5] Geronikaki AA, Gavalas AM. Antioxidants and antiinflammatory diseases: synthetic and natural antioxidants with anti-inflammatory activity, Combinatorial Chemistry \& High Throughput Screening, 2006;9: 425442 .
[6] Ardeshir A, Samaneh O, Yaghooti H, Sistani KN. Effect of royal jelly on formalin induced-inflammation in rat hind paw. Jundishapur Journal of Natural Pharmaceutical, 2015;10: e22466.

[7] Tavga AA, Bushra HM, Zheen AA, Hussain SA. Antiinflammatory activity of Silibinin in animal models of chronic inflammation. American Journal of Pharmacology and Toxicology,2014; 2:17-11.

[8] Ramesh RP, Parasuraman S, Vijaya C, Gopala KSV, Kiran RM. Antiarthritic activity of a polyherbal formulation against Freund's complete adjuvant induced arthritis in female Wistar rats. Journal of Basic and Clinical Pharmarcy, 2015; 6:77-83.

[9] Lourenço JM, Claude J, Galtier N, Chiari Y. Dating cryptodiran nodes: origin and diversification of the turtle superfamily Testudinoidea. Molecular Phylogenetics and Evolution, 2012; 62:496-507.

[10] Habte M, Musoko M. Changes in the vesiculararbuscularmycorrhizal dependency of Albizia ferruginea and Enterolobium cyclocarpum in response to soil phosphorus concentration. Journal of Plant Nutrition, 1994; 17:1769-1780.

[11] Jiofack T, Ayissi I, Fokunang C, Guedje N, Kemeuze C. Ethnobotany and phytomedicine of the upper Nyong valley forest in Cameroon. African Journal of Pharmacy and Pharmacology, 2009;3: 144-150.

[12] Burkill HM. The useful plants of West Africa. $2^{\text {ème }}$ Ed. Royal Botanic Garden. Kew, England; 1995.

[13] Adjanohoun EJ, Adjakidjè V, Ahyi MRA, Aké AL, Akoègninou A, d'Almeida J, Apovo F, Boukef K, Chadare M, Cusset G, Dramane K, Eyme J, Gassita JN, Gbaguidi N, Goudote E, Guinko S, P. Houngnon, Lo I, Keita A, Kiniffo HV, Kone-Bamba D, Musampa NA, Saadou M, Sodogandji T, De Souza S, Tchabi A, Zinsou $\mathrm{CD}$, Zohoun T. Contribution aux études ethnobotaniques et floristiques en République populaire du Bénin. Agence de Coopération Culturelle et Technique, Paris, France ; 1989.

[14] Sarkiyayi S, Karago J, Hassan R. (2011). Studies on Anti Typhoid Properties of Aqueous Methanol Leaves Extract of Albizia ferruginea (Musase). International Journal of Biochemistry Research and Review, 1 (1): 24-30.

[15] Odebeyi OO, Sofowora EA. Phytochemical screening of Nigeria plants 2. LLoydia, 2006; 41: 234-238.

[16] Tanko Y, Kamba B, Saleh M, Musa KY, Mohammed A. Anti-nociceptive and anti-inflammatory activities of ethanolic flower extract of Newbouldia laevis in mice and rats. International Journal of Applied Research in Natural Products, 2008; 1: 13-19.

[17] Singleton V, Draper D. The transfer of polyphenolic compounds from grape seeds into wine. American Journal of Enology and Viticulture, 1964; 15: 34-40.

[18] Zhishen J, Mengcheng T, Jianming W. The determination of flavonoid contents in mulberry and their scavenging effects on superoxide radicals. Journal of Food chemistry and nutrition, 1999; 64:555-559.

[19] Pieme CA, Ngoupayo J, Khou-Kouz Nkoulou CH, Moukette MB, Legrand Njinkio NB, Ama Moor VJ, MinkandeJZ, NgogangJY: Syzyguimguineenseextracts show antioxidant activities and beneficial activities on oxidative stress induced by ferric chloride in the liver homogenate, Antioxidants,2014;3:618-635. 


\section{International Journal of Innovative Research in Medical Science (IJIRMS) Volume 03 Issue 09 Sept. 2018, ISSN: 2455-8737, Imp. Factor - 4.102 \\ Available online at $-\underline{w w w . i j i r m s . i n}$}

[20] Ghate NB, Chaudhuri D, Mandal N. In vitro antioxidant and free radical scavenging assessment of Tinosporacordifolia stem with DNA protective potential. International Journal of Pharmacy and Biological Sciences, 2013;4: 373-388.

[21] Sapna S, Manish PS. Anti-inflammatory activity of quercetin in acute, sub-acute and chronic phases of inflammation in animal models. Journal of Chemical and Pharmaceutical Research, 2013;5: 152-155.

[22] Ighodaro I, Fidelis PC, Aigbe E. Anti-inflammatory activity of aqueous fruit pulp extract of Hunteriaumbellata K. Schum in acute and chronic. ActaPoloniae Pharmaceutica- Drug Research, 2010;67: 81-85.

[23] Fotio AL, Dimo T, Télesphore B, Nguelefack, Ngueguim F, Maria L, Olleros DV, Dongo E, Kamtchouing P, Garcia I. Acute and chronic anti-inflammatory properties of the stem bark aqueous and methanol extracts of Sclerocarya birrea (Anacardiaceae). Journal of Inflammopharmacology, 2009; 17: 229-237.

[24] Gornall AG, Bardawill CJ, David MM. Determination of serum proteins by means of buiret reactions. Journal of Biological Chemistry, 1949;177: 751-766.

[25] Ellman GL. Tissue sulfhydryl group. Archives of Biochemistry and Biophysics, 1959; 82: 70-77.

[26] Misra HP, Fridovich I. The role of super oxide anion in the auto oxidation epinephrine to adrenochrome and a simple assay for superoxide dismutase. Journal of Biology and Chemistry, 1972; 247: 3170-3175.

[27] Sinha K. Colorimetric essay of catalase. Analyze Biochemistry, 1972; 47:389-394.

[28] Wilbur KM, Bernheim F, Shapiro OW. Determination of lipid peroxidation. Archives of Biochemistry and Biophysics, 1949; 24:305-310.

[29] Slack P. Analytical methods manual. $2^{\text {nd }}$ Edition, Bristish food manufacturing industries Research Association, Leatherland, 1987; 5: 644-673.

[30] Bhagat R, Ambavade SD, Misar AV, Kulkarni. Antiinflammatory activity of Jatropha gossypifolia L. leaves in albino mice and Wistar rat. Journal of Scientific and Industrial Research, 2011; 70: 289-292.

[31] Kuby J. Immunology. Freeman and company (éd), américain the book Unversity New York; 1997.

[32] Parmar N, Rawat M, Kumar T. Evaluation of antiinflammatory potential of Kigelia pinnata leaf extract in Wistar rats. Asian Journal of Pharmaceutical and Clinical Research, 2012; 5: 0974-2441.

[33] Vipin KG, Sarvesh KP. Anti-inflammatory activity of aqueous extract of Cynodon dactylon._International Journal of Pharmacology, 2011;7: 370-375.

[34] Woode E, Ainooson GK, Gyasi EB, Ansah C, Obiri DD, Koffour GA, Mensah A, Duwiejua M. Anti-arthritic and antioxidant properties of the ethanolic stem bark extract of Newbouldia laevis (P. Beauv.) Seaman ex Bureau (Bignoniaceae). Journal of medicinal plant research, 2008; 2:180-188.

[35] Ojewole JAO. Evaluation of the anti-inflammatory properties of lerocarya bierra (A. Rich) Hochst. Stem bark extracts in rats. Journal of Ethnopharmacology, 2003, 85: 217-220.

[36] Sudaroli M, Chatterjee TK. Evaluation of red and white seed extracts of Abrus precatorius Linn. Against
Freund's complete adjuvant induced arthritis in rats. Journal of Medicinal Plants Research, 2007;1: 86-94.

[37] Ward JR, Cloud S. Comparative effect of anti-rheumatic drugs on adjuvant induced polyarthritis in rats. Journal of Pharmacology and Experimental Therapeutics, 1965; 152: 121-230.

[38] Dudhgaonkar SP, Kumar D, Naik AR, Bawankule DU, Tandan SK. Interaction of inducible nitric oxide synthase and cyclooxygenase-2 inhibitors in formalin-induced nociception in mice. European Journal of Pharmacology, 2004; 492: 117-122.

[39] Campo GM, Avenoso A, Campo S, Ferlazzo AM, Altavilla D, Calatroni A. Efficacy of treatment with glycosaminoglycans on experimental collagen- induced arthritis in rats. Arthritis Research \& Therapy, 2003;5: R122-R131.

[40] Rasool M, Sabina EP. Anti-inflammatory effect of the Indian ayurvedic herbal formulation triphala on adjuvant-induced arthritis in mice. Phytotherapy Research journal, 2007; 21: 889-894.

[41] Conner EM, Grisham MB. Inflammation free radicals and antioxidant. Journal of Nutrition, 1996;2: 274.

[42] Tamura, Ohmeri. Diacerein suppresses the increase in plasma nitric oxide in rat adjuvant-induced arthritis. European Journal of Pharmacology, 2001; 419:269-274.

[43] Azab S, Abdel-Daim M, Eldahshan O. Phytochemical, cytotoxic, hepatoprotective and anti-oxidant properties of Delonix regia leaves extracy. Medicinal Chemistry Research, 2013; 22:4269-4277.

[44] Jung HJ, Nam JH, Choi J, Lee KT, Park HJ. Antiinflammatory effects of chiisanoside and chiisanogenin obtain from the leaves of Acanthopanax chiisanensis in the carrageenan and Freund's complete adjuvant-induced in rats. J. Ethnopharmacol, 2005; 97: 359-367.

[45] Jain A, Soni M, Deb L, Rout SP, Gupta VB, Krishna KL. Antioxidant and hepatoprotective activity of ethanolic and aqueous extracts of Momordica dioica leaves. Journal of Ethnopharmacology, 2008;115: 61-66.

[46] Mohini AP, Manohar JP, Konde A, Chaudhari PD, Bhoomi P. In-vivo and in-vitro screening of medicinal plants for their anti-inflammatory activity: an overview. Journal of Applied Pharmaceutical Science, 2012;2: 1933.

[47] Padayatty SY, Katz A, Wang Y, Eck P, Kwon O, Lee JH, Chen S, Corpe C, Dutta A, Dutta SK, Levine M. Vitamin $\mathrm{C}$ as antioxidant: Evaluation of its role in disease prevention, Journal of the American College of Nutrition, 2003;22: 18-35.

[48] Frei B, England, Ames BN. Ascorbate is an outstanding in human blood plasma. Proceedings of the National Academy of Sciences, 1989; 86: 6377-6381.

[49] Matsuda H, Morikawa T, Ando S, Toguchida I, Yoshikawa M. Structural requirements of flavonoids for nitric oxide production inhibitory activity and mechanism of action. Bioorganic and Medicinal Chemistry, 2003; 11:1995-2000.

[50] Bauman J, Von Brucch SV, Wurm G. Flavonoids and related compounds as inhibition of arachidonic acid peroxidation. Journal of Ethnopharmacology, 1980; 20: 627-639.

[51] Soobrattee MA, NeergheenVS, Luximon-Ramma A, Aruoma OI, Bahorun T. Phenolics as potential 
antioxidant therapeutic agents: mechanism and actions. Mutation Research, 2005; 579: 200-213.

[52] Sachin VL, Subhash B, Vishwaraman M, Thakurdesai AP. Anti-inflammatory and anti-arthritic activity of typeA procyanidinepolyphenols from bark of Cinnamomum zeylanicum in rats. Food Science and Human Wellness, $2013 ; 2: 59-67$. 